Title: Bio-engineering of bacterial microcompartments - a mini review

Sara Planamente ${ }^{1}$, Stefanie Frank ${ }^{1 *}$

${ }^{1}$ Department of Biochemical Engineering, Bernard Katz Building, Gordon Street, University College London, WC1E 6BT

*Correspondence: stefanie.frank@ucl.ac.uk

\begin{abstract}
Bacterial microcompartments (BMCs) are protein-bound prokaryotic organelles, discovered in cyanobacteria more than 60 years ago. Functionally similar to eukaryotic cellular organelles, BMCs compartment metabolic activities in the cytoplasm, foremost to increase local enzyme concentration and prevent toxic intermediates from damaging the cytosolic content. Advanced knowledge of the functional and structural properties of multiple types of BMCs, particularly over the last 10 years, have highlighted design principles of microcompartments. This has prompted new research into their potential to function as programmable synthetic nanobioreactors and novel bio-materials with biotechnological and medical applications. Moreover, due to the involvement of microcompartments in bacterial pathogenesis and human health, BMCs have begun to gain attention as potential novel drug targets. This mini-review, gives an overview of important synthetic biology developments in the bioengineering of BMCs and a perspective on future directions in the field.
\end{abstract}

\title{
Introduction
}

Bacterial microcompartments (BMCs) are unique protein organelles with dedicated biochemical functions that can be thought of as the prokaryotic equivalent to lipid-bound eukaryotic organelles. These large (50-200 nm diameter) cytosolic structures are composed of a selectively permeable protein shell which encases a number of enzymes associated with specific metabolic activities ${ }^{[1-3]}$. The shell prevents escape of toxic and volatile intermediates into the cytosol, reduces loss of intermediates to side-reactions, increases local enzyme concentration and thus flux through the pathway and accommodates recycling of cofactors ${ }^{[4-}$ 6].

Operons encoding for BMCs are distributed across the bacterial kingdom, with many species encoding for multiple types of microcompartments ${ }^{[7,8]}$. BMCs are functionally diverse and carry out both, anabolic and catabolic processes. The only known anabolic BMCs are $\alpha$ - and $\beta$ carboxysomes in chemoautotrophic species and cyanobacteria. The carboxysome has major implications in global carbon fixation as it houses the enzymes carbonic anhydrase (CA) and Ribulose-1,5-bisphosphate carboxylase/oxygenase (RubisCO), the latter being an enzyme of 
the Calvin-Benson-Bassham cycle that fixes $\mathrm{CO}_{2}$ (Figure 1) ${ }^{[9,10]}$. Catabolic BMCs are termed metabolosomes due to utilisation of organic compounds such as 1,2-propanediol (propanediol utilisation PDU), ethanolamine (ethanolamine utilisation EUT), ethanol (ethanol utilisation ETU), choline (choline utilisation CUT), fucose and rhamnose in heterotrophic bacteria (Figure $1)^{[11-16]}$. The catalytic cores of metabolosomes perform similar biochemical reactions catalysed by a signature enzyme, generating a toxic aldehyde, and a number of aldehyde-processing enzymes: an aldehyde dehydrogenase $(\mathrm{AldDH})$, an alcohol dehydrogenase $(\mathrm{AlcDH})$ and a phosphotransacylase (PTAC) (Figure 1). BMC genes are organised in superloci which include additional genes responsible for a variety of functions such as transcriptional regulation, cofactor synthesis, substrate transport into the cell and organisation of BMCs inside the cell[ ${ }^{[8]}$. Many BMCs, including PDU and EUT BMCs, utilise adenosyl cobalamin ( $\left.\mathrm{B}_{12}\right)$-dependant radical chemistry to convert the substrate into an aldehyde intermediate ${ }^{[17]}$. A recently discovered new class of BMCs, the glycyl radical microcompartment (GRM), uses $B_{12^{-}}$ independent glycyl radical enzymes (GRE) for these reactions and requires external electron sources to form a radical ${ }^{[7]}$. GRMs are a common but comparably understudied class of BMCs and can be divided into five subclasses (GRM1-5) that are metabolising different substrates such as choline and 1,2-propanediol (reviewed here ${ }^{[18,19]}$ ). Notably, GRM as well as EUT and PDU BMCs are encoded by many pathogenic gut bacteria ${ }^{[20-22]}$. There is now clear evidence that BMCs provide competitive fitness advantages and are implicated in bacterial pathogenic behaviour, not only in pathogens but also in otherwise harmless commensals ${ }^{[22,23]}$. Moreover, metabolism of choline has been linked with human cardiovascular disease such as arteriosclerosis $^{[24]}$.

\section{BMC architecture and assembly}

\section{Shell architecture}

Bioengineering of BMCs is based on the understanding of assembly principals of BMC structures. In vivo and in vitro protein interaction studies, X-ray crystallography and electron microscopy (EM) have given detailed insights into the building blocks and molecular details associated with shell assembly ${ }^{[25-27]}$. Crystal structures of more than 40 individual shell proteins and a high-resolution structure of the 6.5-MDa assembled BMC shell from Haliangium ochraceum are now available ${ }^{[3,27,28]}$. The shell of all microcompartments is built from three types of proteins: hexameric proteins $(B M C-H)$, trimeric proteins $(B M C-T)$ and pentameric proteins (BMC-P) (Figure 2A). BMC-H proteins contain a small single BMC domain of $\sim 90$ amino acids (Pfam00936 domain) consisting of an $\alpha / \beta$-fold with four anti-parallel $\beta$-strands surrounded by small helices. BMC domains assemble into homo-hexameric disks with two 
distinct faces, a convex and a concave face. Both, the $\mathrm{N}$ and $\mathrm{C}$ termini are generally located on the concave side of BMC proteins ${ }^{[29,30]}$. BMC-Ts assemble into pseudohexamers, similar in size to BMC-H. Here two BMC domains are located in tandem in the same polypeptide chain and three of these molecules form a trimer (Figure 2A). BMC-P contains a different domain (Pfam03319) that forms a five-stranded anti-parallel $\beta$-barrel and oligomerises into pentamers occupying the vertexes of microcompartments ${ }^{[31]}$. An icosahedral shell will only require 12 pentamer copies. Consequently BMC-P is the least abundant protein in the shell. The faces of the BMC are constructed from BMC-H and BMC-T which form interactions via key amino acid residues at the interfaces ${ }^{[32-34]}$. Selective transport across the shell is mediated via circular pores at the symmetric centre of the hexamers, trimers and pentamers. Small, charged pores ( $\sim \AA \AA$ diameter), typically found in $\mathrm{BMC}-\mathrm{H}$ enable the transport of small substrates and products across the shell, e.g. 1,2-propanediol enters through the pores of $\mathrm{PduA}^{[6,33]}$. Larger cofactors like HS-CoA and NAD ${ }^{+}$are thought to enter the shell through large specialised pores (12-15 $\AA$ ) found in BMC-Ts via a gated mechanism. It has been proposed that the pore opens and closes, controlled by molecule ligands ${ }^{[6,28,35]}$. Some BMC-H and BMC$\mathrm{T}$ proteins contain an $\mathrm{Fe}-\mathrm{S}$ centre in the pore, and have been proposed to facilitate electron transfer between the lumen of the BMC and the cytosol for oxidoreductive reactions ${ }^{[36-38]}$. A much debated question is the orientation of the shell proteins ${ }^{[39]}$. Two models are currently under debate: The "concave-side-in" model favours the $\mathrm{N}$ and $\mathrm{C}$ termini of the BMC protein facing the lumen of the BMC. This is based on computational and experimental interaction studies $^{[32,40,41]}$ suggesting that the C-terminal tails of major shell proteins are important for interaction with enzymes in the lumen of BMCs. In the "concave-side-out" model the concave surface of BMC-H faces towards the cytosol consistent with structural evidence of the $H$. ochraceum microcompartment shell ${ }^{[27]}$ and predictions from in silico modelling on in vitro assembled nanotubes and empty PDU microcompartments ${ }^{[42]}$. Until shell protein orientation is conclusive shell-core interactions and the orientation of pores remain somewhat ambiguous and constrain rational design of BMC proteins.

\section{Interaction between enzymes and shell}

Enzymes residing in the lumen of the shell carry short sequences, $\sim 20$ amino acids, termed encapsulation peptides (EP). These are located on the $\mathrm{N}$ or $\mathrm{C}$ termini or internal regions of the encapsulated enzyme ${ }^{[43]}$. EPs bind to the shell proteins during BMC assembly (Figure $2 \mathrm{~B}$ ). The affinity of the EP-shell interaction is foremost determined by the primary amino acid sequence, the amphipathic nature and the alpha-helical shape of the EP. In PDU BMCs EPs can be found on the propionaldehyde dehydrogenase $P d u P^{[40,43,44]}$, the medium subunit of the diol dehydratase $\mathrm{PduD}^{[3,45]}$, and the phosphotransacylase PduL ${ }^{[4]}$ (all N-terminal). Analogous extensions are present in other BMC systems, for example in the ethanolamine lyase small 
subunit of EutC ${ }^{[46]}$ in the EUT BMC (N-terminal), and in $\mathrm{CcmN}$, a protein required for assembly of the $\beta$ - carboxysome ${ }^{[47]}$ (C-terminal). Some glycyl radical enzymes (GRE) contain putative intra-protein EPs, an indicator that EPs could be engineered between protein domains ${ }^{[48]}$. To date no structural information of an EP-shell protein complex is available. Experimental studies and computational predictions ${ }^{[49]}$ suggest that the C-terminal region of the hexameric shell proteins PduA and PduJ interacts with the N-terminal EPs of cargo protein PduP ${ }^{[40,41]}$. PduP has also been observed to interact with shell protein PduK ${ }^{[44]}$. Furthermore, an $\mathrm{N}$ terminal putative helical region of the PduB shell protein is believed to be critical in binding the entire microcompartment core to the shell[50].

\section{BMC Assembly}

Two BMC assembly mechanisms have been discovered: "Inside out assembly" where an enzyme core forms followed by the shell assembling around it, and "simultaneous assembly" where enzymes and shell proteins interact simultaneously. Evidence for the two mechanisms has been derived from biogenesis studies of carboxysomes ${ }^{[51-57]}$. $\beta$-carboxysomes form through the condensation of the interior enzymes to a so-called "pro-carboxysomal" body. This is facilitated through aggregation of RubisCO by the protein $\mathrm{CcmM}$ which exists in two forms: a full-length M58 which contains a carbonic anhydrase-like domain followed by so-called Rubisco small subunit-like (SSUL) modules connected by unstructured linkers, and a short M35 protein that lacks the carbonic anhydrase like domain ${ }^{[3,54,58-60]}$. The SSULs are homolog to the small subunit of RubisCO and link Rubis $\mathrm{CO}$ molecules in a unique biophysical mechanism to form condensates ${ }^{[54,55]}$. CcmM also recruits carbonic anhydrase (CcaA) via high affinity interaction ${ }^{[61]}$. The $\mathrm{N}$-terminal domain of $\mathrm{CcmM}$ interacts with the $\mathrm{CcmN}$ protein which brings the shell proteins to the enzyme core via its $C$-terminal $\mathrm{EP}^{[47,52]}$. Recent work has shown that $\mathrm{CcmM}$ is not solely concentrated around the core as previously proposed ${ }^{[52]}$ but it is also present deep within the enzyme core ${ }^{[62]}$. This poses future questions about how RubisCO condensation is coordinated with shell recruitment.

In contrast, $\alpha$-carboxysomes co-assemble cargo and shell at the same time by concurrent recruitment of RuBisCO clusters and shell via interactions with the scaffold protein CsoS2 ${ }^{[53]}$. CsoS2 is composed of three distinct regions, the N-region which recruits the shell proteins, a middle (M-region) that coalesces with RuBisCO through the RuBisCO small subunit (CbbS), and the C-region that anchors the growing sheet of assembled shell proteins ${ }^{[53]}$. Furthermore, there is evidence that a short helical motif in the $\mathrm{N}$-terminal domain of the large subunit of RuBisCO ( $\mathrm{CbbL})$ is essential for the encapsulation of the enzyme by interaction with the major shell protein ${ }^{[56]}$. 
According to phylogenetic analysis, the $\beta$-carboxysome shell is structurally more closely related to metabolosomes than to $\alpha$-carboxysomes ${ }^{[10]}$. Interestingly, metabolosomes have been found to contain repeat domains similar to SSULs in $\beta$-carboxysomes. For example, glycyl radical microcompartments contain some enzymes with extensions that mimic a part of the enzyme but are not catalytically active themselves ${ }^{[15,63]}$. These domains could form interactions to bring enzymes together. In metabolosomes, multiple enzymes can oligomerise via coiled coil interactions of their EPs to generate a "pro-metabolosome" prior to encapsulation $^{[64]}$. Enzymes without EPs are "piggybacking" onto enzymes with EPs to ensure enclosure into the shell. Such protein-protein interactions have been observed for a number of enzymes ${ }^{[37,65]}$, for instance the key PDU enzymes, aldehyde dehydrogenase (AldDH containing EP) and alcohol dehydrogenase (ADH lacking EP) ${ }^{[5]}$. Despite a growing understanding of these interactions metabolosome biogenesis is still to be determined.

\section{Engineering of BMCs}

\section{Recombinant expression of whole operons}

$\mathrm{BMC}$ operons are in essence metabolic islands that are horizontally transferrable between bacterial species $^{[66]}$. This has been demonstrated by the first attempt of BMC engineering where the entire PDU BMC operon associated with 1,2-propanediol utilization from Citrobacter freundii was transferred into Escherichia coli to generate fully functional PDU BMCs ${ }^{[67]}$. These compartments were found to be similar in composition, size, shape and mechanical properties to wild type PDU BMCs ${ }^{[68]}$. Since then other transfers of BMC operons, predominantly into $E$. coli, have been undertaken ${ }^{[69]}$ (Table 1). One example is the expression of a complete $\alpha$ carboxysomal gene cluster of the Gram negative bacterium Halothiobacillus neapolitanus in the Gram positive biotechnological species Corynebacterium glutamicum which led to the formation of functional carboxysome-like structures ${ }^{[70]}$. Remarkably, carboxysome genes have also been expressed in the chloroplasts of the plant Nicotiana benthamiana ${ }^{[71]}$ demonstrating that transkingdom expression is possible. Furnishing higher plants with carboxysomes is highly desirable to enhance carbon fixation and productivity in crops.

\section{Synthetic empty BMCs}

BMCs are suitable for compartmentalisation of synthetic multi-enzyme pathways due to their capacity to encapsulate hundreds to thousands of molecules. They have a significantly larger internal volume than natural protein cages or current de novo capsids ${ }^{[72-74]}$. The successful generation of "empty" BMC variants ${ }^{[26,45,46,68,75-77]}$ including PDU compartments 
from C. freundii, EUT compartments from Salmonella enterica ${ }^{[78,79]}$, a microcompartment of unknown function from $H$. ochraceum ${ }^{[26]}$ and a synthetic $\beta$-carboxysome shell from the cyanobacterium Halothece sp. PCC $7418^{[77]}$ marked the first crucial steps towards generation of novel nano-bioreactors (Table 1). Notably, empty BMCs are seemingly smaller than native $\mathrm{BMCs}^{[75,77]}$, indicating that the enzyme core controls the shell dimensions.

Evidence for modularity of BMC proteins has been provided by combining shell proteins from $\alpha$ - and $\beta$-carboxysomes to form chimeric shells ${ }^{[80]}$ or, in another example, by integrating an $\alpha$ carboxysome shell protein from $H$. neapolitanus, a PDU shell protein from $S$. typhimurium, and the a RubisCO large subunit from $H$. neapolitanus into a native $\beta$-carboxysome ${ }^{[81]}$. While mixing and matching of components from different compartments is possible because shell protein homologs share the same essential residues at the edges of proteins ${ }^{[92]}$ the result may not always be functional. This was demonstrated by co-expressing closely-related EUT and PDU BMCs which resulted in non-functional hybrid BMCs due to incorrect interactions among PDU and EUT BMC domain shell proteins ${ }^{[82]}$.

\section{Recruiting enzymes into BMCs}

Non-native enzymes can be directed into the BMC shell by genetic fusion of the protein of interest with a native encapsulation peptide. It is possible to modify the affinity of the EP-shell interaction by amino acid changes in the EP as long as the amphipathic property of the encapsulation peptide is conserved ${ }^{[84]}$. The general interaction mechanism enables encapsulation peptides from different BMCs to be fused to heterologous proteins which in turn can be localised in other types of BMCs. For example, putative EUT and glycyl radical enzyme EPs have been used to direct proteins into a PDU $\mathrm{BMC}^{[85]}$. While this provides useful modularity to a recombinant system, EPs seem relatively inefficient at recruiting cargo, mainly due to low control over stoichiometry, competition with other EPs, and the lack of specificity. Alternative interaction approaches include rational design and library-based screening of de novo encapsulation sequences ${ }^{[86]}$. In a different approach, orthogonal shell-cargo interaction pairs were used instead of EPs ${ }^{[87,88]}$. As a result of attaching one coil of a de novo coiled coil pair to the $\mathrm{N}$ terminus of shell protein $\mathrm{PduA}^{*}$ and the cognate coil to a fluorescent protein, the protein was recruited to the PDU shell ${ }^{[39]}$. Furthermore, directional targeting to either the cytoplasmic side or the lumen of the shell was demonstrated. The latter was facilitated by a permuted version of $\mathrm{PduA}^{*}$. Here, the native $\mathrm{N}$ and $\mathrm{C}$ termini were connected and a new $\mathrm{N}$ terminus, facing the lumen of the PDU BMC, was created on the opposite face of the PduA tile ${ }^{[39]}$. The work assumes that the $\mathrm{N}$ and $\mathrm{C}$ termini of PduA (concave side) face the cytoplasm, as seen in the crystal structure of the synthetic $H$. ochraceum BMC ${ }^{[27,28]}$. However, as discussed earlier, the orientation of the shell proteins in wild type BMCs is still under debate $^{[40,41,50]}$. Regardless, the work by Lee at al. is an important step towards the design of 
the outer and inner surface of BMCs. Encapsulation via covalent linkage (EnCo) has recently been achieved using the SpyTag/SpyCatcher split bacterial adhesin system ${ }^{[89]}$. This allowed multiple proteins to be introduced into the shell at defined ratio ${ }^{[90]}$. Other potential systems for covalent attachment may be the utilisation of split inteins ${ }^{[91]}$ or incorporation of non-natural amino acid residues.

\section{Redesign of a BMC for novel functions}

Multiple GFP variants ${ }^{[26,43,45,78,80]}$ have been targeted to BMCs via fusion to native or synthetic EPs to provide evidence of successful encapsulation and to study encapsulation efficiency ${ }^{[84]}$. The first proof of concept for an encapsulated non-native metabolic pathway was provided by introduction of an alcohol dehydrogenase $(\mathrm{AdhB})$ and a pyruvate decarboxylase $(\mathrm{Pdc})$ from Zymomonas mobilis into an empty $C$. freundii PDU shell and which resulted in increased ethanol production in E. coli ${ }^{[44]}$. Further examples of re-purposing recombinant PDU BMCs include: (i) polyphosphate accumulation for bioremediation ${ }^{[92]}$, (ii) enhanced recombinant expression of a toxic protein ${ }^{[93]}$ and (iii) encapsulation of various enzymes. The latter demonstrated that multimeric or cofactor dependent enzymes retain their activity inside a BMC shell whilst being protected from the cytoplasmic environment ${ }^{[94]}$ (Table 1). These examples $^{[44,92,94]}$ suggest that a range of small non-native substrates and cofactors can cross the shell, except for lipophilic compounds whose diffusion seems restricted ${ }^{[94]}$. However, since there is the possibility that recombinant BMCs are not completely closed the promiscuity of shell proteins for non-native substrates remains ambiguous. If it is necessary to tailor BMC diffusion properties for a pathway of interest the following approaches towards pore design can be used: (i) Modification of the residues lining the pores to mimic pores of other native shell proteins ${ }^{[83,95]}$ and (ii) insertion of shell proteins from one BMC system into another BMC system $^{[80]}$. In the future, these may be applied for a more rational design of custom BMCs.

Assuming complete insulation of a pathway or enzyme is not required, it may not be necessary to fully encapsulate a pathway. Condensing enzymes within the cell in absence of the shell has been shown to increase the metabolic activity of a synthetic pathway of four enzymes. Enzymes fused with native PDU EPs formed a catalytically active protein aggregation in the cytoplasm of $E$. coli, converting glycerol into 1,2-propanediol with productivity increased by $245 \%$ compared to enzymes free in solution ${ }^{[96]}$. Presumably, aggregation is facilitated through coiled coil interactions of the encapsulation peptides.

\section{Ex vivo and in vitro assembly}

While most studies on BMCs have been carried out in vivo major advancements have been made on in vitro assembly ${ }^{[90,97,98]}$. Since BMC proteins self-assemble in vivo, individual shell 
proteins will not readily be available for purification and in vitro assembly. Reduced selfassociation has been observed when fusing shell proteins with affinity purification tags such as the hexa-histidine tag $\left(\mathrm{His}_{6}\right)$. This permitted in vivo production of $\mathrm{His}_{6}-\mathrm{PduA}$ and $\mathrm{His}_{6}-\mathrm{PduB}$, followed by purification and in vitro assembly at low salt conditions after His 6 -tag removal ${ }^{[98]}$. In an alternative approach by Hagen et al., individual shell proteins of the $\mathrm{H}$. ochraceum shell ${ }^{[26,27]}$, a $\beta$-carboxysome and a single $\mathrm{BMC}-\mathrm{H}$ protein $\left(\mathrm{BMC}-\mathrm{H}_{\mathrm{Rmm}}\right)$ from the aminoacetone catabolising Rhodococcus and Mycobacterium microcompartment (RMM) in Mycobacterium smegmatis were translationally fused with a short ubiquitin-like modifier (SUMO) "protecting group". This prevented the formation of macromolecular structures in vivo ${ }^{[97]}$. The proteins were purified, the SUMO tag cleaved and the shell components subsequently mixed in a test tube to assemble three types of supramolecular architectures: a metabolosome shell, a carboxysome shell and a BMC protein-based nanotube. The same technique was applied to build a shell with a positively charged inner surface which enabled electrostatic interactions with a charged protein ${ }^{[97]}$. The HO synthetic BMC (without SUMO) was also produced in vivo without the BMC-P vertex protein, then capped ex vivo by adding purified BMC-Ps tagged with an affinity tag which was subsequently used for BMC purification ${ }^{[90]}$. Furthermore, it was possible to load cargo protein ex vivo by adding protein to uncapped compartments. This promises titration of cargo of any species able to transit the $47 \AA$ diameter pentamer gap.

\section{Self-assembly of shell proteins to form higher architectures}

Shell proteins can form diverse higher-order architectures ranging from flat sheets ${ }^{[99,100]}$, tubes ${ }^{[45,101,102]}$, filaments ${ }^{[67,103]}$ to swiss-role like structures ${ }^{[45]}$ (reviewed here ${ }^{[104]}$ ). The shape and size of the structures has been shown to be modifiable by changes in $\mathrm{pH}$, ionic strength ${ }^{[102]}$ and mutation of key amino acid residues in the hexamer-hexamer interface ${ }^{[101]}$. These structures have enormous potential as biomaterials and for the scaffolding of enzymes. In a recent study by Lee et al. filamentous tubes formed of the PDU shell protein variant PduA* have been utilised as a "cytoscaffold" that was decorated (via coiled coil interactions) with two enzymes for ethanol production ${ }^{[105]}$. Furthermore, localisation of the scaffold to the inner membrane of E. coli was possible, which allowed for the spatial organisation of scaffold and enzymes within the cell.

\section{Practical considerations}

Despite impressive advances in the design and production of recombinant BMCs, a number of challenges need to be considered. Preparation of BMCs is not trivial because heterologous expression often leads to heterogenous and mis-assembled particles. Improved particle formation frequently requires optimisation of expression levels and efficient loading of enzymes of interest. This has been achieved, for example, by adjusting relative timing of BMC 
formation and cargo expression ${ }^{[106]}$ and by addition of a small ssrA degradation tag ${ }^{[64,76,84]}$ to degrade proteins that are not encapsulated. Fusing native EPs to enzymes can severely affect their structure, activity and solubility and as a result can cause aggregation ${ }^{[64]}$. Novel approaches to improved encapsulation, e.g. via synthetic interaction pairs, have been discussed above. But while synthetic fusions to the shell and cargo can be successful, this might not be a universally applicable method as it may impair hexamer-hexamer interactions or affect enzyme activity.

Expression of BMC proteins reportedly has effects on the host cell by changing cell morphology, cell growth and protein interactions with the cytoskeleton ${ }^{[45,67,70,101]}$. This effect is understudied because most recombinant expression studies used $E$. coli. Therefore, it is not well understood how readily synthetic BMCs express and assemble in other hosts. A recent study addressed this issue by screening for the ability of diverse bacterial species to produce functional BMCs by insertion of a broad host plasmid carrying a whole $S$. enterica serovar Typhimurium pdu and cob/cbioperon into these hosts: S. Typhimurium $\Delta p d u, E$. coli, Salmonella bongori, Klebsiella pneumoniae, Cronobacter sakazakii, Serratia marcescens, and different $P$ seudomonas species ${ }^{[69]}$. Such studies may help to identify robust hosts for the expression of synthetic BMCs and may be relevant for synthetic ecology investigations. Many studies use plasmid-based expression systems. Plasmid systems are often unstable due to large numbers of BMC-encoding genes and unsuitable for long-time strain storage. Improved stability might be achieved by genome integration and genomic expression. Alternatively, novel genome editing methods such as CRISPR-Cas9 could be used in future to modify native BMCs in vivo and repurpose for new functionalities.

Finally, industrial scale use of BMCs for biotechnological or medical applications requires a robust bioprocess. To our knowledge, all studies so far have been carried out on laboratory bench scale. It remains to be seen whether recombinant strains can readily be cultured at high-density and at scale without impairing BMC expression and assembly. Implications of cost-effective downstream processing and product recovery will also have to be considered.

\section{Perspective}

(i) Importance of BMCs

- Bacterial microcompartments are modular, programmable protein bioreactors with a large capacity for enzymes. These properties make BMC architectures attractive as nanotechnology platforms with applications in metabolic engineering and biomedicine. 
(ii) Current understanding and challenges

- A variety of BMC architectures can be produced via heterologous expression of the components and functionalised with non-native proteins via non-covalent and covalent interactions. The complexity of BMCs is presenting challenges such as non-optimal protein ratios and inefficient assembly in non-native hosts that will need to be overcome.

(iii) Future directions (Figure 3)

- Rational design of novel BMCs and high-throughput screening via cell-free expression systems should allow for the production of "à la carte" BMCs in prokaryotic and eukaryotic hosts. For industrial applications, scale-up and bioprocess development will be required. 


\section{Conflict of interest}

The authors declare no conflict of interest.

\section{Abbreviation list}

$\mathrm{BMC}=$ Bacterial microcompartment

$E P=$ Encapsulation peptide

$\mathrm{SE}=$ Signature enzyme

GRM= Glycyl radical microcompartments

GRE $=$ Glycyl radical enzymes

RubisCO= Ribulose-1,5-bisphosphate carboxylase/oxygenase

$\mathrm{Ccm}=$ Carbon dioxide-concentrating mechanism 


\section{Figures and tables}

Figure 1. Metabolic pathways and organisation of BMCs. Sketches representing generic features of $\alpha$ - and $\beta$-carboxysomes (left) and metabolosomes (right) with their associated metabolic pathways. Shell proteins are represented as coloured squares forming hexagonal structures within which enzymes and products are shown with the following nomenclature: $\mathrm{CA}=$ carbonic anhydrase; $3-\mathrm{PGA}=3$-phosphoglycerate RuBP = ribulose 1,5-bisphosphate; the $\mathrm{CBB}$ cyle= Calvin-Benson-Bassham; $\mathrm{SE}=$ signature enzyme; $\mathrm{AldH}=$ aldehyde dehydrogenase ; $\mathrm{AlcDH}=$ alcohol dehydrogenase $; \mathrm{PTAC}=$ phosphotransacylase; $\mathrm{R}-\mathrm{OH}=$ alcohol product; $\mathrm{R}-\mathrm{CHO}=$ aldehyde; $\mathrm{R}-\mathrm{P}=$ phosphorylated product.

The metabolic pathways within BMCs are here briefly described. Carboxysomes encapsulate CA which provides $\mathrm{CO}_{2}$ to RuBisCO, a key step of the CBB cycle, where the BMC's shell prevents the loss of $\mathrm{CO}_{2}$ into the cytoplasm. Metabolosomes use a range of substrates (listed on the left). Once transported into the metabolosome lumen, these substrates are converted via so-called signature enzymes into aldehyde, a toxic intermediate. Signature enzymes are specific to certain types of BMCs. For example, the signature enzyme for the substrate ethanolamine is ethanolamine ammonia lyase and the enzyme produces acetaldehyde and ammonia $^{[8]}$. It is important to highlight that the metabolosome shell prevents these toxic compounds being released into the cytoplasm. The aldehyde is subsequently converted into $\mathrm{R}-\mathrm{CoA}$ or $\mathrm{R}-\mathrm{OH}$. Conversion to R-CoA requires $\mathrm{NAD}^{+}$, which is provided by AldDH.

Figure 2. Shell proteins and BMCs assembly. Schematic representation of the structures of the shell proteins BMC-H (blue), BMC-T (pink), and BMC-P (green) and core enzymes are shown in panel A. BMC-T can be found in the single trimer form $\left(B M C-\mathrm{T}^{\mathrm{s}}\right)$ and as two trimers dimerising along the concave face which is referred to as double BMC-T (BMC-T ${ }^{d}$ ). Pfam domain identification numbers (Pf00xxx) of the corresponding shell proteins are indicated. The EP (when associated with core enzymes) is represented as a black helix, a scaffolding enzyme such as CcmM is shown in brown, enzymes without EP are shown in green. B, Sketch representing the generic assembly process of BMCs: the core enzymes/encapsulation peptide can assemble first or together with shell proteins to form fully assembled BMCs. EM images (right) showing purified PDU metabolosomes from C. freundii (modified from ${ }^{[68]}$ ).

Figure 3. Overview of future approaches of BMC engineering. A, a library of individual or multiple BMC "parts" can be produced in vivo or in vitro. The parts can be further assembled in order to engineer "à la carte" BMCs. Red extensions denote affinity tags for BMC 
purification. Blue triangles indicate protecting groups that stop shell proteins from selfassembling. B, A representative strategy to use BMC components as scaffold building blocks is shown. Here BMC shell proteins are genetically fused with synthetic interacting parts (coiled-coil peptides or covalent pairs) and produced together with enzymes of interest that are fused with interacting counterparts. This would allow physical proximity of the enzymes with controlled stoichiometry and enhance flux and ultimately, product formation. Letters A-D are substrates/products of a designed pathway.

Figure 1

Figure 2

Figure 3

Table 1: Representative examples of BMC engineering 


\section{References}

[1] Chowdhury C, Sinha S, Chun S, Yeates TO, Bobik TA. (2014) Diverse bacterial microcompartment organelles. Microbiol. Mol. Biol. Rev. [Internet]. 78, 438-68. Available from: http://www.ncbi.nlm.nih.gov/pubmed/25184561

[2] Bobik TA, Lehman BP, Yeates TO. (2015) Bacterial microcompartments: widespread prokaryotic organelles for isolation and optimization of metabolic pathways. Mol. Microbiol. [Internet]. Available from:

http://www.ncbi.nlm.nih.gov/pubmed/26148529

[3] Kerfeld CA, Aussignargues C, Zarzycki J, Cai F, Sutter M. (2018) Bacterial microcompartments. Nat. Rev. Microbiol. [Internet]. 16, 277-290. Available from: http://www.nature.com/doifinder/10.1038/nrmicro.2018.10

[4] Erbilgin O, Sutter M, Kerfeld CA. (2016) The Structural Basis of Coenzyme A Recycling in a Bacterial Organelle. PLOS Biol. [Internet]. 14, e1002399. Available from: http://www.ncbi.nlm.nih.gov/pubmed/26959993

[5] Cheng S, Fan C, Sinha S, Bobik TA. (2012) The PduQ Enzyme Is an Alcohol Dehydrogenase Used to Recycle NAD+ Internally within the Pdu Microcompartment of Salmonella enterica. PLoS One [Internet]. 7, e47144. Available from: http://dx.plos.org/10.1371/journal.pone.0047144

[6] Chowdhury C, Chun S, Pang A, Sawaya MR, Sinha S, Yeates TO, et al. (2015) Selective molecular transport through the protein shell of a bacterial microcompartment organelle. Proc. Natl. Acad. Sci. [Internet]. 112, 2990-2995. Available from: http://www.pnas.org/lookup/doi/10.1073/pnas.1423672112

[7] Jorda J, Lopez D, Wheatley NM, Yeates TO. (2013) Using comparative genomics to uncover new kinds of protein-based metabolic organelles in bacteria. Protein Sci. [Internet]. 22, 179-195. Available from: http://doi.wiley.com/10.1002/pro.2196

[8] Axen SD, Erbilgin O, Kerfeld CA. (2014) A taxonomy of bacterial microcompartment loci constructed by a novel scoring method. PLoS Comput. Biol. [Internet]. 10, e1003898. Available from:

http://journals.plos.org/ploscompbiol/article?id=10.1371/journal.pcbi.1003898

[9] Cannon GC, Bradburne CE, Aldrich HC, Baker SH, Heinhorst S, Shively JM. (2001) Microcompartments in Prokaryotes: Carboxysomes and Related Polyhedra. Appl. Environ. Microbiol. [Internet]. 67, 5351-5361. Available from: https://aem.asm.org/content/67/12/5351.full?ijkey=45632f55fb7e8dd4239aec6180a c012337a6c76d\&keytype2=tf_ipsecsha

[10] Kerfeld CA, Melnicki MR. (2016) Assembly, function and evolution of cyanobacterial carboxysomes. Curr. Opin. Plant Biol. [Internet]. 31, 66-75. Available from: https://www.sciencedirect.com/science/article/pii/S136952661630036X?via\%3Dihub

[11] Bobik TA, Havemann GD, Busch RJ, Williams DS, Aldrich HC. (1999) The propanediol utilization (pdu) operon of Salmonella enterica serovar Typhimurium LT2 includes genes necessary for formation of polyhedral organelles involved in coenzyme $B(12)$ dependent 1, 2-propanediol degradation. J Bacteriol [Internet]. 181, 5967-5975. Available from:

http://www.ncbi.nlm.nih.gov/entrez/query.fcgi?cmd=Retrieve\&db=PubMed\&dopt=C itation\&list_uids $=10498708$

[12] Kofoid E, Rappleye C, Stojiljkovic I, Roth J. (1999) The 17-Gene Ethanolamine (eut) Operon of Salmonella typhimurium Encodes Five Homologues of Carboxysome Shell Proteins. J. Bacteriol. [Internet]. 181, 5317-5329. Available from: 
http://jb.asm.org/content/181/17/5317.full

[13] Erbilgin O, McDonald KL, Kerfeld CA. (2014) Characterization of a planctomycetal organelle: a novel bacterial microcompartment for the aerobic degradation of plant saccharides. Appl. Environ. Microbiol. [Internet]. 80, 2193-205. Available from: http://www.ncbi.nlm.nih.gov/pubmed/24487526

[14] Herring TI, Harris TN, Chowdhury C, Mohanty SK, Bobik TA. (2018) A Bacterial Microcompartment Is Used for Choline Fermentation by Escherichia coli 536. J. Bacteriol. [Internet]. 200, e00764-17. Available from:

http://www.ncbi.nlm.nih.gov/pubmed/29507086

[15] Jameson E, Fu T, Brown IR, Paszkiewicz K, Purdy KJ, Frank S, et al. (2016) Anaerobic choline metabolism in microcompartments promotes growth and swarming of Proteus mirabilis. Environ. Microbiol. 18.

[16] Petit E, LaTouf WG, Coppi M V., Warnick TA, Currie D, Romashko I, et al. (2013) Involvement of a Bacterial Microcompartment in the Metabolism of Fucose and Rhamnose by Clostridium phytofermentans. PLoS One [Internet]. 8, e54337. Available from: http://dx.plos.org/10.1371/journal.pone.0054337

[17] Bobik TA, Xu Y, Jeter RM, Otto KE, Roth JR. (1997) Propanediol utilization genes (pdu) of Salmonella typhimurium: three genes for the propanediol dehydratase. J Bacteriol [Internet]. 179, 6633-9. Available from: http://www.ncbi.nlm.nih.gov/htbinpost/Entrez/query?db=m\&form $=6 \& d o p t=r \& u i d=9352910$

[18] Zarzycki J, Erbilgin O, Kerfeld CA. (2015) Bioinformatic Characterization of Glycyl Radical Enzyme-Associated Bacterial Microcompartments. Appl. Environ. Microbiol. [Internet]. 81, AEM.02587-15. Available from: http://aem.asm.org/lookup/doi/10.1128/AEM.02587-15

[19] Ferlez B, Sutter M, Kerfeld CA. (2019) Glycyl Radical Enzyme-Associated Microcompartments: Redox-Replete Bacterial Organelles. MBio [Internet]. 10, e02327-18. Available from: http://www.ncbi.nlm.nih.gov/pubmed/30622187

[20] Jakobson CM, Tullman-Ercek D, Fan C, Cheng S, Liu Y, Escobar C, et al. (2016) Dumpster Diving in the Gut: Bacterial Microcompartments as Part of a HostAssociated Lifestyle. PLOS Pathog. [Internet]. 12, e1005558. Available from: http://dx.plos.org/10.1371/journal.ppat.1005558

[21] Garsin DA. (2010) Ethanolamine utilization in bacterial pathogens: roles and regulation. Nat. Rev. Microbiol. [Internet]. 8, 290-5. Available from:

http://www.pubmedcentral.nih.gov/articlerender.fcgi?artid=2950637\&tool=pmcentr ez\&rendertype=abstract

[22] Kaval KG, Garsin DA. (2018) Ethanolamine Utilization in Bacteria. Available from: https://doi.org/10.1128/mBio

[23] Patel D, Witt SN. (2017) Ethanolamine and Phosphatidylethanolamine: Partners in Health and Disease. Oxid. Med. Cell. Longev. [Internet]. 2017, 4829180. Available from: http://www.ncbi.nlm.nih.gov/pubmed/28785375

[24] Characterization and Detection of a Widely Distributed Gene Cluster That Predicts Anaerobic Choline Utilization by Human Gut Bacteria [Internet]. Available from: http://mbio.asm.org/content/6/2/e00042-15.full.pdf

[25] Kerfeld CA, Sawaya MR, Tanaka S, Nguyen C V, Phillips M, Beeby M, et al. (2005) Protein structures forming the shell of primitive bacterial organelles. Science [Internet]. 309, 936-8. Available from: http://www.ncbi.nlm.nih.gov/pubmed/16081736 
[26] Lassila JK, Bernstein SL, Kinney JN, Axen SD, Kerfeld CA. (2014) Assembly of Robust Bacterial Microcompartment Shells Using Building Blocks from an Organelle of Unknown Function. J. Mol. Biol. [Internet]. 426, 2217-2228. Available from: https://www.sciencedirect.com/science/article/pii/S0022283614001260

[27] Sutter M, Greber B, Aussignargues C, Kerfeld CA. (2017) Assembly principles and structure of a 6.5-MDa bacterial microcompartment shell. Science (80-. ). [Internet]. 356, 1293-1297. Available from: http://science.sciencemag.org/content/356/6344/1293.abstract

[28] Greber BJ, Sutter M, Kerfeld CA. (2019) The Plasticity of Molecular Interactions Governs Bacterial Microcompartment Shell Assembly. Structure [Internet]. Available from: https://www.sciencedirect.com/science/article/pii/S0969212619300176?via\%3Dihub \#fig3

[29] Kerfeld CA, Heinhorst S, Cannon GC. (2010) Bacterial Microcompartments. Annu. Rev. Microbiol. [Internet]. 64, 391-408. Available from: http://www.annualreviews.org/doi/10.1146/annurev.micro.112408.134211

[30] Yeates TO, Crowley CS, Tanaka S. (2010) Bacterial Microcompartment Organelles: Protein Shell Structure and Evolution. Annu. Rev. Biophys. [Internet]. 39, 185-205. Available from:

http://www.annualreviews.org/doi/10.1146/annurev.biophys.093008.131418

[31] Tanaka S, Kerfeld CA, Sawaya MR, Cai F, Heinhorst S, Cannon GC, et al. (2008) AtomicLevel Models of the Bacterial Carboxysome Shell. Science (80-. ). [Internet]. 319, 1083-1086. Available from: http://www.ncbi.nlm.nih.gov/pubmed/18292340

[32] Tanaka S, Sawaya MR, Phillips M, Yeates TO. (2008) Insights from multiple structures of the shell proteins from the $\beta$-carboxysome. Protein Sci. [Internet]. 18, NA-NA. Available from: http://doi.wiley.com/10.1002/pro.14

[33] Crowley CS, Cascio D, Sawaya MR, Kopstein JS, Bobik TA, Yeates TO. (2010) Structural insight into the mechanisms of transport across the Salmonella enterica Pdu microcompartment shell. J. Biol. Chem. [Internet]. 285, 37838-46. Available from: http://www.pubmedcentral.nih.gov/articlerender.fcgi?artid=2988387\&tool=pmcentr ez\&rendertype $=$ abstract

[34] Kerfeld CA, Erbilgin O. (2015) Bacterial microcompartments and the modular construction of microbial metabolism. Trends Microbiol. [Internet]. 23, 22-34. Available from: http://www.sciencedirect.com/science/article/pii/S0966842X14002121

[35] Larsson AM, Hasse D, Valegård K, Andersson I. (2017) Crystal structures of $\beta$ carboxysome shell protein CcmP: ligand binding correlates with the closed or open central pore. J. Exp. Bot. [Internet]. 68, 3857-3867. Available from: https://academic.oup.com/jxb/article/68/14/3857/3091906

[36] Pang A, Warren MJ, Pickersgill RW, IUCr. (2011) Structure of PduT, a trimeric bacterial microcompartment protein with a 4Fe-4S cluster-binding site. Acta Crystallogr. Sect. D Biol. Crystallogr. [Internet]. 67, 91-96. Available from: http://scripts.iucr.org/cgibin/paper?S0907444910050201

[37] Parsons JB, Lawrence AD, McLean KJ, Munro AW, Rigby SEJ, Warren MJ. (2010) Characterisation of PduS, the pdu Metabolosome Corrin Reductase, and Evidence of Substructural Organisation within the Bacterial Microcompartment. PLoS One [Internet]. 5, e14009. Available from: 
http://dx.plos.org/10.1371/journal.pone.0014009

[38] Thompson MC, Wheatley NM, Jorda J, Sawaya MR, Gidaniyan SD, Ahmed H, et al. (2014) Identification of a Unique Fe-S Cluster Binding Site in a Glycyl-Radical Type Microcompartment Shell Protein. J. Mol. Biol. [Internet]. 426, 3287-3304. Available from:

https://www.sciencedirect.com/science/article/pii/S0022283614003660?via\%3Dihub

[39] Lee MJ, Mantell J, Brown IR, Fletcher JM, Verkade P, Pickersgill RW, et al. (2018) De novo targeting to the cytoplasmic and luminal side of bacterial microcompartments. Nat. Commun. [Internet]. 9, 3413. Available from: http://www.nature.com/articles/s41467-018-05922-x

[40] Fan C, Cheng S, Sinha S, Bobik TA. (2012) Interactions between the termini of lumen enzymes and shell proteins mediate enzyme encapsulation into bacterial microcompartments. Proc. Natl. Acad. Sci. [Internet]. 109, 14995-15000. Available from: http://www.ncbi.nlm.nih.gov/pubmed/22927404

[41] Jorda J, Liu Y, Bobik TA, Yeates TO. (2015) Exploring Bacterial Organelle Interactomes: A Model of the Protein-Protein Interaction Network in the Pdu Microcompartment. PLOS Comput. Biol. [Internet]. 11, e1004067. Available from: http://dx.plos.org/10.1371/journal.pcbi.1004067

[42] Uddin I, Frank S, Warren MJMJ, Pickersgill RWRW. (2018) A Generic Self-Assembly Process in Microcompartments and Synthetic Protein Nanotubes. Small [Internet]. 14, 1704020. Available from: http://doi.wiley.com/10.1002/smll.201704020

[43] Fan C, Cheng S, Liu Y, Escobar CM, Crowley CS, Jefferson RE, et al. (2010) Short Nterminal sequences package proteins into bacterial microcompartments. Proc. Natl. Acad. Sci. [Internet]. 107, 7509-7514. Available from: http://www.ncbi.nlm.nih.gov/pubmed/20308536

[44] Lawrence AD, Frank S, Newnham S, Lee MJ, Brown IR, Xue W-F, et al. (2014) Solution Structure of a Bacterial Microcompartment Targeting Peptide and Its Application in the Construction of an Ethanol Bioreactor.

[45] Parsons JB, Frank S, Bhella D, Liang M, Prentice MB, Mulvihill DP, et al. (2010) Synthesis of Empty Bacterial Microcompartments, Directed Organelle Protein Incorporation, and Evidence of Filament-Associated Organelle Movement. Mol. Cell. 38, 305-315.

[46] Choudhary S, Quin MB, Sanders MA, Johnson ET, Schmidt-Dannert C. (2012) Engineered Protein Nano-Compartments for Targeted Enzyme Localization. PLoS One [Internet]. 7, e33342. Available from: https://dx.plos.org/10.1371/journal.pone.0033342

[47] Kinney JN, Salmeen A, Cai F, Kerfeld CA. (2012) Elucidating essential role of conserved carboxysomal protein $\mathrm{CcmN}$ reveals common feature of bacterial microcompartment assembly. J. Biol. Chem. [Internet]. 287, 17729-36. Available from: http://www.ncbi.nlm.nih.gov/pubmed/22461622

[48] Zarzycki J, Sutter M, Cortina NS, Erb TJ, Kerfeld CA. (2017) In Vitro Characterization and Concerted Function of Three Core Enzymes of a Glycyl Radical Enzyme Associated Bacterial Microcompartment. Sci. Rep. [Internet]. 7, 42757. Available from: http://www.nature.com/articles/srep42757

[49] Youssef NH, Farag IF, Rinke C, Hallam SJ, Woyke T, Elshahed MS, et al. (2015) In Silico Analysis of the Metabolic Potential and Niche Specialization of Candidate Phylum \&quot;Latescibacteria\&quot; (WS3). PLoS One [Internet]. 10, e0127499. Available 
from: http://dx.plos.org/10.1371/journal.pone.0127499

[50] Lehman BP, Chowdhury C, Bobik TA. (2017) The N Terminus of the PduB Protein Binds the Protein Shell of the Pdu Microcompartment to Its Enzymatic Core. J. Bacteriol. [Internet]. 199. Available from: http://www.ncbi.nlm.nih.gov/pubmed/28138097

[51] Chen AH, Robinson-Mosher A, Savage DF, Silver PA, Polka JK. (2013) The Bacterial Carbon-Fixing Organelle Is Formed by Shell Envelopment of Preassembled Cargo. PLoS One [Internet]. 8, e76127. Available from: https://dx.plos.org/10.1371/journal.pone.0076127

[52] Cameron JC, Wilson SC, Bernstein SL, Kerfeld CA. (2013) Biogenesis of a bacterial organelle: the carboxysome assembly pathway. Cell [Internet]. 155, 1131-40. Available from: http://www.ncbi.nlm.nih.gov/pubmed/24267892

[53] Cai F, Dou Z, Bernstein SL, Leverenz R, Williams EB, Heinhorst S, et al. (2015) Advances in Understanding Carboxysome Assembly in Prochlorococcus and Synechococcus Implicate CsoS2 as a Critical Component. Life (Basel, Switzerland) [Internet]. 5, 1141-71. Available from: http://www.ncbi.nlm.nih.gov/pubmed/25826651

[54] Wang H, Yan X, Aigner H, Bracher A, Nguyen ND, Hee WY, et al. (2019) Rubisco condensate formation by $\mathrm{CcmM}$ in $\beta$-carboxysome biogenesis. Nature [Internet]. 566, 131-135. Available from: http://www.nature.com/articles/s41586-019-0880-5

[55] Ryan P, Forrester TJB, Wroblewski C, Kenney TMG, Kitova EN, Klassen JS, et al. (2019) The small RbcS-like domains of the $\beta$-carboxysome structural protein $\mathrm{CcmM}$ bind RubisCO at a site distinct from that binding the RbcS subunit. J. Biol. Chem. [Internet]. 294, 2593-2603. Available from: http://www.ncbi.nlm.nih.gov/pubmed/30591587

[56] Liu Y, He X, Lim W, Mueller J, Lawrie J, Kramer L, et al. (2018) Deciphering molecular details in the assembly of alpha-type carboxysome. Sci. Rep. [Internet]. 8, 15062. Available from: http://www.nature.com/articles/s41598-018-33074-x

[57] Dai W, Chen M, Myers C, Ludtke SJ, Pettitt BM, King JA, et al. (2018) Visualizing Individual RuBisCO and Its Assembly into Carboxysomes in Marine Cyanobacteria by Cryo-Electron Tomography. J. Mol. Biol. [Internet]. 430, 4156-4167. Available from: https://www.sciencedirect.com/science/article/pii/S002228361830411X

[58] Long BM, Tucker L, Badger MR, Price GD. (2010) Functional cyanobacterial betacarboxysomes have an absolute requirement for both long and short forms of the CcmM protein. Plant Physiol. [Internet]. 153, 285-93. Available from: http://www.ncbi.nlm.nih.gov/pubmed/20304968

[59] Cole JR, Wang Q, Cardenas E, Fish J, Chai B, Farris RJ, et al. (2009) The Ribosomal Database Project: improved alignments and new tools for rRNA analysis. Nucleic Acids Res. [Internet]. 37, D141-D145. Available from: https://academic.oup.com/nar/article-lookup/doi/10.1093/nar/gkn879

[60] Long BM, Badger MR, Whitney SM, Price GD. (2007) Analysis of carboxysomes from Synechococcus PCC7942 reveals multiple Rubisco complexes with carboxysomal proteins CcmM and CcaA. J. Biol. Chem. [Internet]. 282, 29323-35. Available from: http://www.ncbi.nlm.nih.gov/pubmed/17675289

[61] McGurn LD, Moazami-Goudarzi M, White SA, Suwal T, Brar B, Tang JQ, et al. (2016) The structure, kinetics and interactions of the $\beta$-carboxysomal $\beta$-carbonic anhydrase, CcaA. Biochem. J. [Internet]. 473, 4559-4572. Available from: http://www.ncbi.nlm.nih.gov/pubmed/27729545

[62] Niederhuber MJ, Lambert TJ, Yapp C, Silver PA, Polka JK. (2017) Superresolution 
microscopy of the $\beta$-carboxysome reveals a homogeneous matrix. Mol. Biol. Cell [Internet]. 28, 2734-2745. Available from:

http://www.molbiolcell.org/doi/10.1091/mbc.e17-01-0069

[63] Zarzycki J, Erbilgin O, Kerfeld CA. (2015) Bioinformatic characterization of glycyl radical enzyme-associated bacterial microcompartments. Appl. Environ. Microbiol. [Internet]. 81, 8315-29. Available from: http://www.ncbi.nlm.nih.gov/pubmed/26407889

[64] Lee MJ, Brown IR, Juodeikis R, Frank S, Warren MJ. (2016) Employing bacterial microcompartment technology to engineer a shell-free enzyme-aggregate for enhanced 1,2-propanediol production in Escherichia coli. Metab. Eng. 36.

[65] Cheng S, Bobik TA. (2010) Characterization of the PduS cobalamin reductase of Salmonella enterica and its role in the Pdu microcompartment. J. Bacteriol. [Internet]. 192, 5071-80. Available from: http://www.ncbi.nlm.nih.gov/pubmed/20656910

[66] Abdul-Rahman F, Petit E, Blanchard JL. (2013) The Distribution of Polyhedral Bacterial Microcompartments Suggests Frequent Horizontal Transfer and Operon Reassembly. J Phylogen Evol. Biol [Internet]. 1, 4. Available from: https://pdfs.semanticscholar.org/ff16/7b0b44af0353f9b64c76590e7ff166cf972c.pdf

[67] Parsons JB, Dinesh SD, Deery E, Leech HK, Brindley AA, Heldt D, et al. (2008) Biochemical and structural insights into bacterial organelle form and biogenesis. J. Biol. Chem. 283.

[68] Mayer MJMJ, Juodeikis R, Brown IRIRIR, Frank S, Palmer DJDJ, Deery E, et al. (2016) Effect of bio-engineering on size, shape, composition and rigidity of bacterial microcompartments. Sci. Rep. [Internet]. 6, 36899. Available from: http://www.ncbi.nlm.nih.gov/pubmed/27845382

[69] Graf L, Wu K, Wilson JW. (2018) Transfer and analysis of Salmonella pdu genes in a range of Gram-negative bacteria demonstrate exogenous microcompartment expression across a variety of species. Microb. Biotechnol. [Internet]. 11, 199-210. Available from: http://doi.wiley.com/10.1111/1751-7915.12863

[70] Baumgart M, Huber I, Abdollahzadeh I, Gensch T, Frunzke J. (2017) Heterologous expression of the Halothiobacillus neapolitanus carboxysomal gene cluster in Corynebacterium glutamicum. J. Biotechnol. [Internet]. 258, 126-135. Available from: https://linkinghub.elsevier.com/retrieve/pii/S0168165617301244

[71] Lin MT, Occhialini A, Andralojc PJ, Devonshire J, Hines KM, Parry MAJ, et al. (2014) $\beta$ Carboxysomal proteins assemble into highly organized structures in Nicotiana chloroplasts. Plant J. [Internet]. 79, 1-12. Available from:

http://www.ncbi.nlm.nih.gov/pubmed/24810513

[72] Giessen TW. (2016) Encapsulins: microbial nanocompartments with applications in biomedicine, nanobiotechnology and materials science. Curr. Opin. Chem. Biol. [Internet]. 34, 1-10. Available from: http://www.ncbi.nlm.nih.gov/pubmed/27232770

[73] Azuma Y, Edwardson TGW, Hilvert D. (2018) Tailoring lumazine synthase assemblies for bionanotechnology. Chem. Soc. Rev. [Internet]. 47, 3543-3557. Available from: http://xlink.rsc.org/?DOI=C8CS00154E

[74] Bale JB, Gonen S, Liu Y, Sheffler W, Ellis D, Thomas C, et al. (2016) Accurate design of megadalton-scale two-component icosahedral protein complexes. Science [Internet]. 353, 389-94. Available from: http://www.ncbi.nlm.nih.gov/pubmed/27463675

[75] Mayer MJ, Juodeikis R, Brown IR, Frank S, Palmer DJ, Deery E, et al. (2016) Effect of 
bio-engineering on size, shape, composition and rigidity of bacterial microcompartments. Sci. Rep. 6.

[76] Sargent F, Davidson FA, Kelly CL, Binny R, Christodoulides N, Gibson D, et al. (2013) A synthetic system for expression of components of a bacterial microcompartment. Microbiology [Internet]. 159, 2427-36. Available from: http://www.ncbi.nlm.nih.gov/pubmed/24014666

[77] Cai F, Bernstein SL, Wilson SC, Kerfeld CA. (2016) Production and Characterization of Synthetic Carboxysome Shells with Incorporated Luminal Proteins. Plant Physiol. [Internet]. 170, 1868-77. Available from: http://www.ncbi.nlm.nih.gov/pubmed/26792123

[78] Quin MB, Perdue SA, Hsu S-YY, Schmidt-Dannert C. (2016) Encapsulation of multiple cargo proteins within recombinant Eut nanocompartments. Appl. Microbiol. Biotechnol. [Internet]. 100, 9187-9200. Available from: http://link.springer.com/10.1007/s00253-016-7737-8

[79] Choudhary S, Quin MB, Sanders MA, Johnson ET, Schmidt-Dannert C. (2012) Engineered protein nano-compartments for targeted enzyme localization. PLoS One [Internet]. 7, e33342. Available from: http://www.ncbi.nlm.nih.gov/pubmed/22428024

[80] Cai F, Sutter M, Bernstein SL, Kinney JN, Kerfeld CA. Engineering Bacterial Microcompartment Shells: Chimeric Shell Proteins and Chimeric Carboxysome Shells.

[81] Fang Y, Huang F, Faulkner M, Jiang Q, Dykes GF, Yang M, et al. (2018) Engineering and Modulating Functional Cyanobacterial CO2-Fixing Organelles. Front. Plant Sci. [Internet]. 9. Available from: https://www.frontiersin.org/article/10.3389/fpls.2018.00739/full

[82] Sturms R, Streauslin NA, Cheng S, Bobik TA. (2015) In Salmonella enterica, Ethanolamine Utilization Is Repressed by 1,2-Propanediol To Prevent Detrimental Mixing of Components of Two Different Bacterial Microcompartments. J. Bacteriol. [Internet]. 197, 2412-21. Available from: http://www.ncbi.nlm.nih.gov/pubmed/25962913

[83] Slininger Lee MF, Jakobson CM, Tullman-Ercek D. (2017) Evidence for Improved Encapsulated Pathway Behavior in a Bacterial Microcompartment through Shell Protein Engineering. ACS Synth. Biol. [Internet]. 6, 1880-1891. Available from: http://pubs.acs.org/doi/10.1021/acssynbio.7b00042

[84] Kim EY, Tullman-Ercek D. (2014) A rapid flow cytometry assay for the relative quantification of protein encapsulation into bacterial microcompartments. Biotechnol. J. [Internet]. 9, 348-354. Available from: http://www.ncbi.nlm.nih.gov/pubmed/24323373

[85] Jakobson CM, Kim EY, Slininger MF, Chien A, Tullman-Ercek D. (2015) Localization of proteins to the 1,2-propanediol utilization microcompartment by non-native signal sequences is mediated by a common hydrophobic motif. J. Biol. Chem. [Internet]. 290, 24519-33. Available from: http://www.ncbi.nlm.nih.gov/pubmed/26283792

[86] Jakobson CM, Slininger Lee MF, Tullman-Ercek D. (2017) De novo design of signal sequences to localize cargo to the 1,2-propanediol utilization microcompartment. Protein Sci. [Internet]. 26, 1086-1092. Available from: http://doi.wiley.com/10.1002/pro.3144

[87] Fletcher JM, Harniman RL, Barnes FRH, Boyle AL, Collins A, Mantell J, et al. (2013) Self-Assembling Cages from Coiled-Coil Peptide Modules. Science (80-. ). [Internet]. 
340, 595-599. Available from: http://www.ncbi.nlm.nih.gov/pubmed/23579496

[88] Thomas F, Boyle AL, Burton AJ, Woolfson DN. (2013) A Set of de Novo Designed Parallel Heterodimeric Coiled Coils with Quantified Dissociation Constants in the Micromolar to Sub-nanomolar Regime. J. Am. Chem. Soc. [Internet]. 135, 5161-5166. Available from: http://pubs.acs.org/doi/10.1021/ja312310g

[89] Zakeri B, Fierer JO, Celik E, Chittock EC, Schwarz-Linek U, Moy VT, et al. (2012) Peptide tag forming a rapid covalent bond to a protein, through engineering a bacterial adhesin. Proc. Natl. Acad. Sci. U. S. A. [Internet]. 109, E690-7. Available from: http://www.ncbi.nlm.nih.gov/pubmed/22366317

[90] Hagen A, Sutter M, Sloan N, Kerfeld CA. (2018) Programmed loading and rapid purification of engineered bacterial microcompartment shells. Nat. Commun. [Internet]. 9, 2881. Available from: http://www.nature.com/articles/s41467-01805162-z

[91] Li Y. (2015) Split-inteins and their bioapplications. Biotechnol. Lett. [Internet]. 37, 2121-2137. Available from: http://link.springer.com/10.1007/s10529-015-1905-2

[92] Liang M, Frank S, Lünsdorf H, Warren MJ, Prentice MB. (2017) Bacterial microcompartment-directed polyphosphate kinase promotes stable polyphosphate accumulation in E. coli. Biotechnol. J. 12.

[93] Yung MC, Bourguet FA, Carpenter TS, Coleman MA. (2017) Re-directing bacterial microcompartment systems to enhance recombinant expression of lysis protein $E$ from bacteriophage $\phi X 174$ in Escherichia coli. Microb. Cell Fact. [Internet]. 16, 71. Available from: https://search-proquestcom.libproxy.ucl.ac.uk/docview/1895834209?rfr_id=info\%3Axri\%2Fsid\%3Aprimo

[94] Wagner HJ, Capitain CC, Richter K, Nessling M, Mampel J. (2017) Engineering bacterial microcompartments with heterologous enzyme cargos. Eng. Life Sci. [Internet]. 17, 36-46. Available from: http://doi.wiley.com/10.1002/elsc.201600107

[95] Aussignargues C, Pandelia M-E, Sutter M, Plegaria JS, Zarzycki J, Turmo A, et al. (2016) Structure and Function of a Bacterial Microcompartment Shell Protein Engineered to Bind a [4Fe-4S] Cluster. J. Am. Chem. Soc. [Internet]. 138, 5262-5270. Available from: http://pubs.acs.org/doi/10.1021/jacs.5b11734

[96] Lee MJMJ, Brown IRIR, Juodeikis R, Frank S, Warren MJMJ. (2016) Employing bacterial microcompartment technology to engineer a shell-free enzyme-aggregate for enhanced 1,2-propanediol production in Escherichia coli. Metab. Eng. [Internet]. 36, 48-56. Available from: http://www.sciencedirect.com/science/article/pii/S1096717616000288

[97] Hagen AR, Plegaria JS, Sloan N, Ferlez B, Aussignargues C, Burton R, et al. (2018) In Vitro Assembly of Diverse Bacterial Microcompartment Shell Architectures. Nano Lett. [Internet]. 18, 7030-7037. Available from: http://pubs.acs.org/doi/10.1021/acs.nanolett.8b02991

[98] Uddin I, Frank S, Warren MJ, Pickersgill RW. (2018) A Generic Self-Assembly Process in Microcompartments and Synthetic Protein Nanotubes. Small. 14.

[99] Dryden KA, Crowley CS, Tanaka S, Yeates TO, Yeager M. (2009) Two-dimensional crystals of carboxysome shell proteins recapitulate the hexagonal packing of threedimensional crystals. Protein Sci. [Internet]. 18, 2629. Available from: http://www.ncbi.nlm.nih.gov/pubmed/19844993

[100] Sutter M, Faulkner M, Aussignargues C, Paasch BC, Barrett S, Kerfeld CA, et al. (2016) Visualization of Bacterial Microcompartment Facet Assembly Using High-Speed 
Atomic Force Microscopy. Nano Lett. [Internet]. 16, 1590-1595. Available from: http://pubs.acs.org/doi/10.1021/acs.nanolett.5b04259

[101] Pang A, Frank S, Brown I, Warren MJ, Pickersgill RW. (2014) Structural insights into higher order assembly and function of the bacterial micro compartment protein PduA. J. Biol. Chem. 289.

[102] Noël CR, Cai F, Kerfeld CA. (2016) Purification and Characterization of Protein Nanotubes Assembled from a Single Bacterial Microcompartment Shell Subunit. Adv. Mater. Interfaces [Internet]. 3, 1500295. Available from: http://doi.wiley.com/10.1002/admi.201500295

[103] Heldt D, Frank S, Seyedarabi A, Ladikis D, Parsons JB, Warren MJ, et al. (2009) Structure of a trimeric bacterial microcompartment shell protein, EtuB, associated with ethanol utilization in Clostridium kluyveri. Biochem. J. 423, 199-207.

[104] Young EJ, Burton R, Mahalik JP, Sumpter BG, Fuentes-Cabrera M, Kerfeld CA, et al. (2017) Engineering the Bacterial Microcompartment Domain for Molecular Scaffolding Applications. Front. Microbiol. [Internet]. 8, 1441. Available from: http://journal.frontiersin.org/article/10.3389/fmicb.2017.01441/full

[105] Lee MJ, Mantell J, Hodgson L, Alibhai D, Fletcher JM, Brown IR, et al. (2018) Engineered synthetic scaffolds for organizing proteins within the bacterial cytoplasm. Nat. Chem. Biol. 14.

[106] Jakobson CM, Chen Y, Slininger MF, Valdivia E, Kim EY, Tullman-Ercek D. (2016) Tuning the Catalytic Activity of Subcellular Nanoreactors. J. Mol. Biol. [Internet]. 428, 2989-2996. Available from:

https://linkinghub.elsevier.com/retrieve/pii/S0022283616302510 
Table 1: Representative examples of BMC engineering

\begin{tabular}{|c|c|c|c|}
\hline Purpose & Description of components & Expression host & References \\
\hline & $\begin{array}{l}\text { pdu operon of Citrobacter freundii } \\
\text { a-carboxysome regulon from } \\
\text { Halothiobacillus neapolitanus } \\
\beta \text {-carboxysomes from Synechoccus. } \\
\text { elongatus PCC7942 } \\
\text { a-carboxysome gene cluster of } H \text {. } \\
\text { neaplitanus } \\
12 \beta \text {-carboxysome genes of } S \text {. elongatus } \\
\text { PCC7942 } \\
\text { Broad host plasmid carrying a whole } S \text {. } \\
\text { enterica serovar Typhimurium pdu and } \\
\text { cob/cbi genes operon }\end{array}$ & $\begin{array}{l}\text { Escherichia coli } \\
\text { E. coli } \\
\text { Nicotiana } \\
\text { benthamania } \\
\text { chloroplasts } \\
\text { Corynebacterium } \\
\text { glutamicum } \\
\text { E. coli } \\
\text { Many different Gram } \\
\text { negative hosts }\end{array}$ & $\begin{array}{l}\text { Parsons et al. } \\
2008^{[67]} \\
\text { Bonacci et al. } \\
2012^{[107]} \\
\text { Lin et al. 2014 } \\
\text { B71] } \\
\text { Baumgart et al. } \\
\text { Fang et al. } \\
\text { 2018 } \\
\text { Grof] } \\
\text { Graf et al. }\end{array}$ \\
\hline $\mathrm{Em}$ & $\begin{array}{l}\text { PDU shell proteins from C. freundii } \\
\text { EUT shell proteins from Salmonella } \\
\text { enterica } \\
\text { Shell of BMC of unknown function from } \\
\text { Haliangium ochraceum } \\
\text { Synthetic } \beta \text {-carboxysome shell from } \\
\text { Halothece PCC7418 } \\
\text { PDU shell proteins from } C \text {. freundii }\end{array}$ & $\begin{array}{l}\text { E. coli } \\
\text { E. coli } \\
\text { E. coli } \\
\text { E. coli } \\
\text { C. glutamicum }\end{array}$ & $\begin{array}{l}\text { Parsons et al. } \\
2010^{[45]} \\
\text { Choudhary et al. } \\
2012^{[46]} \text {, Quin et } \\
\text { al. 2016[78] } \\
\text { Lassila et al. } \\
2014^{[26]} \\
\text { Cai et al. } \\
2016^{[77]} \\
\text { Huber et al. } \\
2017^{[108]}\end{array}$ \\
\hline $\begin{array}{l}\text { Encapsulation of } \\
\text { heterologous } \\
\text { proteins }\end{array}$ & $\begin{array}{l}\text { PduP }{ }^{1-18} \text {-eGFP and PduP }{ }^{1-18} \text {-GST } \\
\text { fusions } \\
\text { PduC and PduD from C. freundii fused to } \\
\text { GFP targeted to recombinant PDU shell } \\
\text { EutC }^{1-19} \text {-eGFP, EutC }{ }^{1-19} \text {-ß-galactosidase } \\
\text { targeted to empty EUT shell (S. enterica) } \\
\text { H. ochraceum aldehyde dehydrogenase } \\
\text { (full length or EP) fused with GFP, } \\
\text { targeted to empty H. ochraceum shell } \\
\text { Increased ethanol production: alcohol } \\
\text { dehydrogenase (AdhB) and a pyruvate } \\
\text { decarboxylase (Pdc) from Zymomonas } \\
\text { mobilis fused with PduP and PduD EPs } \\
\text { from C. freundii and targeted into empty } \\
\text { PDU shell }\end{array}$ & $\begin{array}{l}\text { S. enterica } \\
\text { E. coli } \\
\text { E.coli } \\
\text { E. coli } \\
\text { E. coli }\end{array}$ & $\begin{array}{l}\text { Fan et al. } \\
2010^{[43]} \\
\text { Parsons et al. } \\
2010^{[45]} \\
\text { Choudhary et al. } \\
2012^{[46]} \\
\text { Lassila et al. } \\
2014^{[26]} \\
\\
\text { Lawrence et al. } \\
\text { 2014 }\end{array}$ \\
\hline
\end{tabular}




\begin{tabular}{|c|c|c|c|}
\hline & $\begin{array}{l}\text { EutC }{ }^{1-19} \text {-eGFP and EutE } E^{1-21} \text {-eGFP interact } \\
\text { with same shell protein EutS in empty } \\
\text { EUT shell } \\
\beta \text {-carboxysomal CcmN }{ }^{211-258} \text { fused to the } \\
\text { C terminus of GFP, targeted into synthetic } \\
\text { carboxysome shell } \\
\text { PduP }{ }^{1-18-P K K 1 ~(p o l y p h o s p h a t e ~ k i n a s e) ~} \\
\text { targeted into empty PDU shell } \\
\text { Enhanced recombinant expression of lysis } \\
\text { protein E from bacteriophage } \varphi \text { X174: EPs } \\
\text { of PduD, PduP, EutC fused with lysis } \\
\text { protein E and targeted into EUT or PDU } \\
\text { shell } \\
\text { Esterase Est5 from soil metagenome, } \beta \text { - } \\
\text { galactosidase and NADH-dependent } \\
\text { glycerol dehydrogenase (GIdA) from } E \text {. } \\
\text { coli, targeted to PDU BMC shell, } \\
\text { protection against external pH stress }\end{array}$ & $\begin{array}{l}\text { E. coli } \\
\text { E. coli } \\
\text { E. coli } \\
\text { E. coli } \\
\text { E. coli }\end{array}$ & $\begin{array}{l}\text { Quin et al. } \\
2016^{[78]} \\
\text { Cai et al. } \\
2016^{[77]} \\
\text { Liang et al. } \\
2017^{[92]} \\
\text { Yung et al. } \\
2017^{[93]} \\
\\
\text { Wagner et al. } \\
2017^{[94]}\end{array}$ \\
\hline $\begin{array}{l}\text { Shell-free } \\
\text { aggregates }\end{array}$ & $\begin{array}{l}\text { Increased 1,2-propanediol production by } \\
\text { enzyme aggregation via coiled coil } \\
\text { interaction of native EPs: glycerol } \\
\text { dehydrogenase, dihydroxyacetone kinase, } \\
\text { methylglyoxal synthase and 1,2- } \\
\text { propanediol oxidoreductase fused with } \\
\text { PduP and PduD EPs }\end{array}$ & E. coli & $\begin{array}{l}\text { Lee et al. } \\
2016^{[64]}\end{array}$ \\
\hline $\begin{array}{l}\text { Scaffolding of } \\
\text { heterologous } \\
\text { proteins }\end{array}$ & $\begin{array}{l}\text { Citrine, mCherry and alcohol } \\
\text { dehydrogenase, pyruvate decarboxylase } \\
\text { from Z. mobilis attached to a PduA* } \\
\text { filament using coiled coil interactions, } \\
\text { increased production of ethanol compared } \\
\text { to non-scaffolded enzymes }\end{array}$ & E. coli & $\begin{array}{l}\text { Lee et al. } \\
2018^{[105]}\end{array}$ \\
\hline $\begin{array}{l}\text { In vitro } \\
\text { assembly \& ex } \\
\text { vivo cargo } \\
\text { loading }\end{array}$ & $\begin{array}{l}\text { In vivo production of shell proteins from } H \text {. } \\
\text { ochraceum shell, } \beta \text {-carboxysome and } \\
\text { single BMC-H protein (BMC-HRm) from } \\
\text { Mycobacterium smegmatis fused with } \\
\text { protecting group (SUMO), SUMO tag } \\
\text { cleaved, shell components subsequently } \\
\text { mixed in tube to assemble a } \\
\text { metabolosome shell, a carboxysome } \\
\text { shell, and a BMC protein-based nanotube } \\
\text { H. ochraceum shell produced in vivo } \\
\text { without the BMC-P vertex protein, then } \\
\text { capped in vitro by adding BMC-Ps, } \\
\text { fluorescent cargo protein loaded ex vivo } \\
\text { by adding proteins to uncapped } \\
\text { compartments, then capped and purified. }\end{array}$ & $\begin{array}{l}\text { E. coli/ in vitro } \\
\text { E. coli/ ex vivo }\end{array}$ & $\begin{array}{l}\text { Hagen et al. } \\
2018^{[97]} \\
\text { Hagen et al. } \\
2018^{[90]}\end{array}$ \\
\hline
\end{tabular}


References are included in the main document 


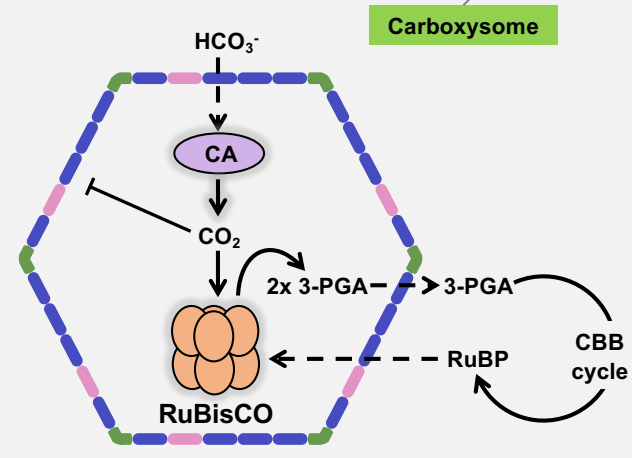

\section{Metabolosome}

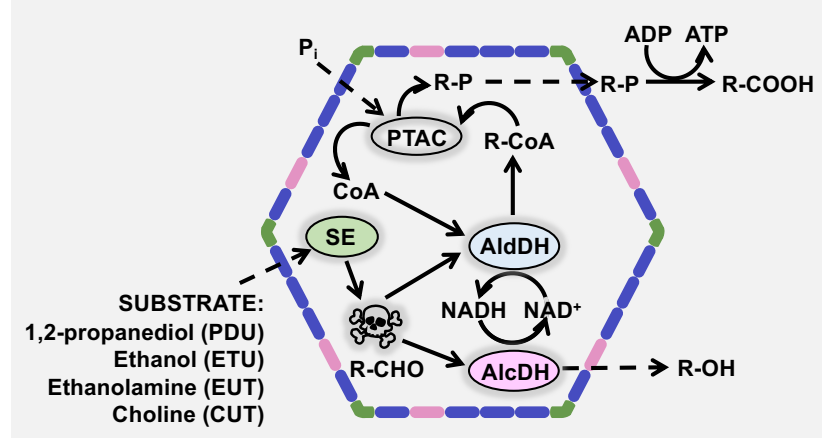


A

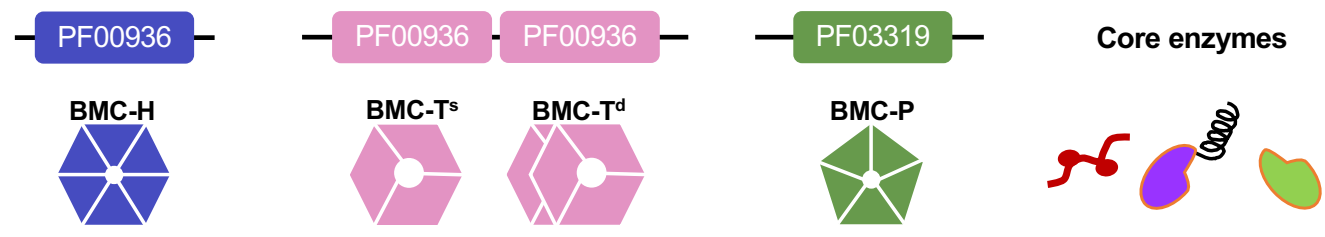

B

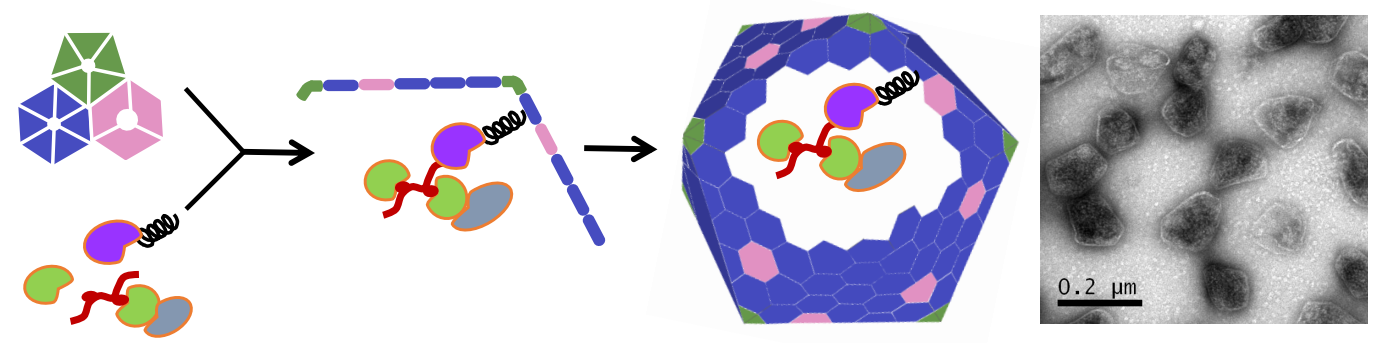



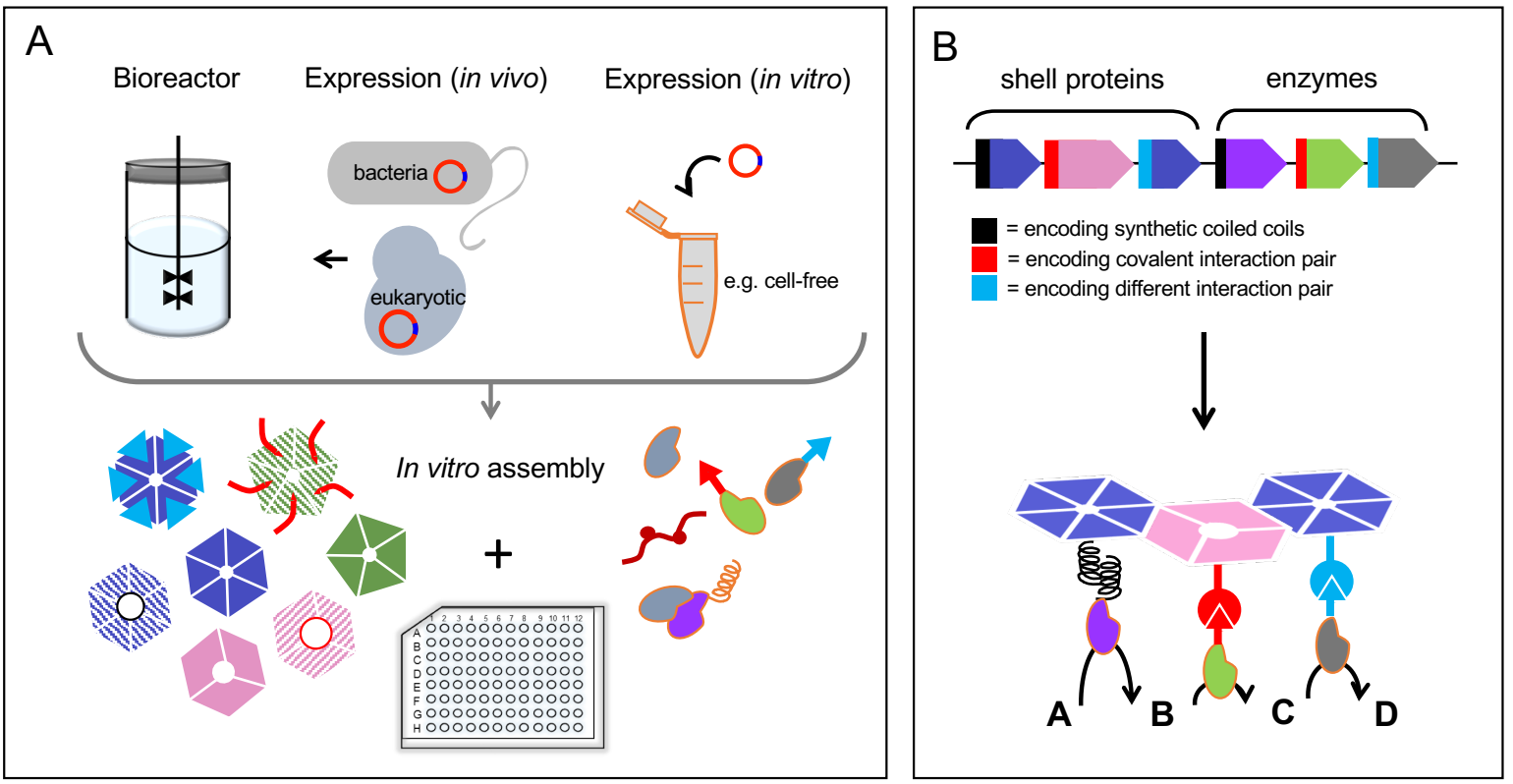